\title{
One Size Fits All? The Validity of a Composite Poverty Index Across Urban and Rural Households in South Africa
}

\author{
Janina Isabel Steinert ${ }^{1} \cdot$ Lucie Dale Cluver ${ }^{1,2}$ • \\ G. J. Melendez-Torres ${ }^{3} \cdot$ Sebastian Vollmer $^{4,5}$
}

Accepted: 19 December 2016/Published online: 27 December 2016

(C) The Author(s) 2016. This article is published with open access at Springerlink.com

\begin{abstract}
Composite indices have been prominently used in poverty research. However, validity of these indices remains subject to debate. This paper examines the validity of a common type of composite poverty indices using data from a cross-sectional survey of 2477 households in urban and rural KwaZulu-Natal, South Africa. Multiple-group comparisons in structural equation modelling were employed for testing differences in the measurement model across urban and rural groups. The analysis revealed substantial variations between urban and rural respondents both in the conceptualisation of poverty as well as in the weights and importance assigned to individual poverty indicators. The validity of a 'one size fits all' measurement model can therefore not be confirmed. In consequence, it becomes virtually impossible to determine a household's poverty level relative to the full sample. Findings from our analysis have important practical implications in nuancing how we can sensitively use composite poverty indices to identify poor people.
\end{abstract}

Janina Isabel Steinert

janina.steinert@spi.ox.ac.uk

Lucie Dale Cluver

lucie.cluver@spi.ox.ac.uk

G. J. Melendez-Torres

G.Melendez-Torres@warwick.ac.uk

Sebastian Vollmer

svollmer@uni-goettingen.de

1 Department of Social Policy and Intervention, University of Oxford, Barnett House, 32 Wellington Square, Oxford OX1 2ER, UK

2 Department of Psychiatry and Mental Health, University of Cape Town, Cape Town, South Africa

3 Warwick Medical School, University of Warwick, Coventry CV4 7AL, UK

4 Chair of Development Economics, University of Göttingen, Platz der Göttinger Sieben 3, 37073 Göttingen, Germany

5 Department of Global Health and Population, Harvard T.H. Chan School of Public Health, Boston, MA, USA 
Keywords Asset indices · Multidimensional poverty $\cdot$ Poverty indices · Structural equation modelling · Validity

\section{Introduction}

Composite indices have been critical to the understanding of poverty in both research and policy. One of the most widely used examples is the Human Development Index (HDI) that has been developed by the United Nations Development Program. The HDI seeks to measure household wealth and wellbeing by aggregating a range of welfare-related aspects into an overall index and then ranking countries according to their performance on the three dimensions of life expectancy, education, and income per capita. In a similar vein, asset indices have been widely used for the measurement of household welfare (e.g. Filmer and Scott 2012; Carter and Barrett 2006; Sahn and Stifel 2000, 2003; Filmer and Pritchett 2001; Moser and Felton 2007). An asset index is defined so that household wealth increases (numerically) with the possession of more durables/assets and a higher standard of living, for instance through access to electricity and running water. The Demographic and Health Survey collects extensive data on quality of housing and household assets in the majority of low- and middle-income countries and has thus further promoted reliance on these indices. Another example of a composite measurement is the Multidimensional Poverty Index (MPI) that was developed by the Oxford Poverty and Human Development Initiative (OPHI) and has gained international standing over the past decade. The MPI assesses individual deprivation profiles based on a set of ten indicators including aspects of nutrition, mortality, schooling, and decent standards of living. For each of these ten indicators, individuals are classified as 'deprived' or 'non-deprived' based on pre-defined cut-offs. Countries are then ranked according to the headcount ratio of people who experience multiple deprivations (Alkire et al. 2016a, b; Alkire and Santos 2014; OPHI 2013; Alkire and Foster 2011; Ferreira and Lugo 2013). From 2010 onwards, the MPI has been integrated in the Human Development Report that is released annually by the United Nations Development Program (UNDP 2010).

Despite widespread use, the validity of composite poverty indices remains contested. Sahn and Stifel (2003) and Filmer and Pritchett (2001) demonstrate the robustness of such indices, particularly when it comes to identifying the poorest groups of society (Klasen 2000). However, others have questioned their adequacy when used over time and across space (Harttgen et al. 2013; Saisana et al. 2005). A commonly cited concern is the use of 'one-size-fits-all' measurement approaches across urban and rural locations (Chakraborty et al. 2016; Douidich et al. 2015; Stifel and Christiaensen 2007; Vyas and Kumaranayake 2006). For instance, OPHI has now moved towards disaggregating MPI rankings for urban and rural populations (Alkire et al. 2016b) and Rutstein (2008) advocates for the application of urban- and rural-specific DHS Wealth Index. Yet, despite these cautionary tales, composite poverty indicators are still commonly used without taking sub-national (as well as cross-national) heterogeneity into account, both in high-level policy reports (World Bank 2015; UNDP 2015; OECD 2015) as well as academic outlets (Hruschka et al. 2015; Smits and Steendijk 2014; Batana 2013; Michelson et al. 2013; Booysen et al. 2008). The present analysis draws upon these two strands of literature by generating further empirical evidence to demonstrate that the rural-urban divide does matter for aggregated poverty indices. We draw on data across urban and rural locations of the KwaZulu-Natal province 
in South Africa. Significant disparities in urban and rural locations of South Africa mirror former spatial policies of the Apartheid regime (Daniels et al. 2013; Klasen 2000). Previous studies have identified large gaps in levels of income and deprivation (Klasen 2000; Sahn and Stifel 2000), employment (Turok 2012), or receipt of governmental grants (Daniels et al. 2013) between urban and rural households. Income migration to peri-urban and urban centres has further shaped these spatial disparities in South Africa (Posel 2004). KwaZulu-Natal's population is a largely homogenous ethnic group (Zulu) and the same political party has governed the former homeland since 1994. The province therefore appears an ideal location for isolating differences between urban and rural areas from some important potential confounders.

\section{Data and Methods}

\subsection{Data}

The analysis uses data from a larger study ${ }^{1}$ in KwaZulu-Natal, South Africa. Data were collected between 2009 and 2010, sampling both deep rural (Manguzi/kwaNgwanase) and peri-urban (Lamontville/Umlazi townships) communities of the province. The sampling methodology followed the South African census model of stratified systematic random sampling. Stratification was done per census enumeration area or per designated tribal area in rural locations that were identified through Geographical Information System. Respondents were then selected through door-to-door household sampling. A 10-17-year-old child/adolescent was randomly selected in each household and asked to identify his/her primary caregiver, defined as the person living with and responsible for the day-to-day care of the child. While the child survey put focus on a range of psychosocial outcomes; household characteristics and socioeconomic information were collected via caregiver reports. The present analysis therefore draws on cross-sectional data from the household survey with 2477 caregivers. Face-to-face interviews were conducted by local research assistants in isiZulu with both adolescents and their primary caregivers. Participation was voluntary and informed consent was sought from all respondents. The ethical protocol was approved by the University of Oxford, the University of KwaZulu-Natal, and the provincial Department of Health and Education (see also Cluver et al. 2013). Sociodemographic information was collected using items from the South African Census (2001) and the South Africa General Household Survey. Indicators for housing quality and ownership of assets were based on the Demographic and Health Surveys (DHS). All measures are specified in detail in "Appendix".

\subsection{Construction of a Composite Poverty Index}

For the purpose of this paper, we operationalize poverty in the form of a composite index that aggregates a range of individual indicators into a scalar score. The core idea hereby is to move beyond material aspects and capture the broader dimensions of wellbeing such as health, education, or social capital (Sen 1993). Based on a review of the literature on poverty measurements, Table 1 provides a comprehensive overview of the different indicators conventionally used for the construction of poverty indices. Although there are some variations in the number and kind of indicators, most approaches have covered three main dimensions reflective of individuals' experienced deprivation and poverty. A first

1 Young Carers Project South Africa: http://www.youngcarers.org.za/young-carers/. 
Table 1 Poverty indicators: overview

\begin{tabular}{|c|c|c|}
\hline Indicator & Prior application & Relation to poverty \\
\hline Safe drinking water & $\begin{array}{l}\text { Qi and Wu (2014), Harttgen et al. (2013), } \\
\text { Échevin (2013), DHS (2012), Alkire } \\
\text { and Foster (2011), UNDP (2010), Sahn } \\
\text { and Stifel (2003), Battiston et al. } \\
\text { (2013), Booysen et al. (2008), Klasen } \\
\text { (2000), Montgomery et al. (2000) }\end{array}$ & $\begin{array}{l}\text { Access to clean water can improve } \\
\text { hygiene and general health. Household } \\
\text { access to a source of clean water can } \\
\text { free up productive time from fetching } \\
\text { water }\end{array}$ \\
\hline $\begin{array}{l}\text { Toilet facilities } \\
\text { (e.g. flush toilet } \\
\text { or pit latrine) }\end{array}$ & $\begin{array}{l}\text { Qi and Wu (2014), Harttgen et al. (2013), } \\
\text { Échevin (2013), DHS (2012), Alkire } \\
\text { and Foster (2011), UNDP (2010), } \\
\text { Battiston et al. (2013), Wright (2008), } \\
\text { Booysen et al. (2008), Moser and } \\
\text { Felton (2007), Sahn and Stifel (2003), } \\
\text { Filmer and Pritchett (2001) }\end{array}$ & $\begin{array}{l}\text { Good sanitation can improve hygiene and } \\
\text { general health }\end{array}$ \\
\hline Cooking fuel & $\begin{array}{l}\text { Qi and Wu (2014), DHS (2012), Alkire } \\
\text { and Foster (2011), UNDP (2010), Sahn } \\
\text { and Stifel (2003), Filmer and Pritchett } \\
\text { (2001), Klasen (2000) }\end{array}$ & $\begin{array}{l}\text { Use of unprocessed solids leads to indoor } \\
\text { air pollution, poor respiratory health } \\
\text { and is correlated with high accident } \\
\text { rates }\end{array}$ \\
\hline Heating fuel & Qi and Wu (2014) & $\begin{array}{l}\text { Indoor air pollution and high accident } \\
\text { rates }\end{array}$ \\
\hline Lighting & $\begin{array}{l}\text { Moser and Felton (2007), Filmer and } \\
\text { Pritchett (2001) }\end{array}$ & General housing quality \\
\hline $\begin{array}{l}\text { Number of rooms/ } \\
\text { over-crowding }\end{array}$ & $\begin{array}{l}\text { Échevin (2013), DHS (2012), Wright } \\
\text { (2008), Filmer and Pritchett (2001) }\end{array}$ & $\begin{array}{l}\text { Several person per sleeping room is } \\
\text { related to increased transmission of } \\
\text { respiratory illnesses }\end{array}$ \\
\hline Electricity & $\begin{array}{l}\text { Qi and Wu (2014), DHS (2012), Alkire } \\
\text { and Foster (2011), UNDP (2010), } \\
\text { Wright (2008), Montgomery et al. } \\
(2000)\end{array}$ & General housing quality \\
\hline Floor & $\begin{array}{l}\text { Qi and Wu (2014), Harttgen et al. (2013), } \\
\text { Échevin (2013), DHS (2012), Alkire } \\
\text { and Foster (2011), UNDP (2010), } \\
\text { Booysen et al. (2008), Moser and } \\
\text { Felton (2007), Sahn and Stifel (2003), } \\
\text { Montgomery et al. (2000) }\end{array}$ & General housing quality \\
\hline Wall & $\begin{array}{l}\text { Harttgen et al. (2013), DHS (2012), } \\
\text { Battiston et al. (2013), Moser and } \\
\text { Felton (2007) }\end{array}$ & General housing quality \\
\hline Dwelling & $\begin{array}{l}\text { DHS (2012), Wright (2008), de Kruijk } \\
\text { and Rutten (2007), Filmer and Pritchett } \\
\text { (2001) }\end{array}$ & General housing quality \\
\hline Bicycle/motorcycle & $\begin{array}{l}\text { Qi and Wu (2014), Harttgen et al. (2013), } \\
\text { Ferreira and Lugo (2013), Échevin } \\
\text { (2013), DHS (2012), UNDP (2010), } \\
\text { Booysen et al. (2008), Wright (2008), } \\
\text { Moser and Felton (2007), Sahn and } \\
\text { Stifel (2003), Filmer and Pritchett } \\
\text { (2001), Klasen (2000), Montgomery } \\
\text { et al. (2000) }\end{array}$ & $\begin{array}{l}\text { Basic transportation is linked to better } \\
\text { access to healthcare and } \\
\text { community/social life }\end{array}$ \\
\hline Car & $\begin{array}{l}\text { Échevin (2013), DHS (2012), Alkire and } \\
\text { Foster (2011), UNDP (2010), Wright } \\
\text { (2008), Moser and Felton (2007), } \\
\text { Klasen (2000), Montgomery et al. } \\
\text { (2000) }\end{array}$ & $\begin{array}{l}\text { Transport affects the ability to participate } \\
\text { in labor market and society }\end{array}$ \\
\hline
\end{tabular}


Table 1 continued

\begin{tabular}{|c|c|c|}
\hline Indicator & Prior application & Relation to poverty \\
\hline Refrigerator & $\begin{array}{l}\text { Qi and Wu (2014), Harttgen et al. (2013), } \\
\text { Ferreira and Lugo (2013), DHS (2012), } \\
\text { Alkire and Foster (2011), Échevin } \\
\text { (2013), Booysen et al. (2008), Wright } \\
\text { (2008), Moser and Felton (2007), Sahn } \\
\text { and Stifel (2003), Filmer and Pritchett } \\
\text { (2001), Klasen (2000), Montgomery } \\
\text { et al. (2000) }\end{array}$ & $\begin{array}{l}\text { Household wealth accumulated in } \\
\text { durables/assets }\end{array}$ \\
\hline Washing machine & $\begin{array}{l}\text { Qi and Wu (2014), DHS (2012), Wright } \\
\text { (2008), Moser and Felton (2007) }\end{array}$ & $\begin{array}{l}\text { Household wealth accumulated in } \\
\text { durables/assets }\end{array}$ \\
\hline TV & $\begin{array}{l}\text { Qi and Wu (2014), Harttgen et al. (2013), } \\
\text { Ferreira and Lugo (2013), Échevin } \\
\text { (2013), DHS (2012), Alkire and Foster } \\
\text { (2011),UNDP (2010), Wright (2008), } \\
\text { Booysen et al. (2008), Moser and } \\
\text { Felton (2007), Sahn and Stifel (2003), } \\
\text { Filmer and Pritchett (2001), Klasen } \\
\text { (2000), Montgomery et al. (2000) }\end{array}$ & $\begin{array}{l}\text { Household wealth accumulated in } \\
\text { durables/assets }\end{array}$ \\
\hline Computer & $\begin{array}{l}\text { Qi and Wu (2014), Moser and Felton } \\
\text { (2007) }\end{array}$ & $\begin{array}{l}\text { Household wealth accumulated in } \\
\text { durables/assets }\end{array}$ \\
\hline Telephone & $\begin{array}{l}\text { Qi and Wu (2014), Ferreira and Lugo } \\
\text { (2013), DHS (2012), Alkire and Foster } \\
\text { (2011), UNDP (2010), Wright (2008), } \\
\text { Klasen (2000) }\end{array}$ & $\begin{array}{l}\text { Household wealth accumulated in } \\
\text { durables/assets }\end{array}$ \\
\hline Radio & $\begin{array}{l}\text { Harttgen et al. (2013), Échevin (2013), } \\
\text { DHS (2012), UNDP (2010), Wright } \\
\text { (2008), Booysen et al. (2008), Moser } \\
\text { and Felton (2007), Sahn and Stifel } \\
\text { (2003), Filmer and Pritchett (2001), } \\
\text { Montgomery et al. (2000) }\end{array}$ & $\begin{array}{l}\text { Household wealth accumulated in } \\
\text { durables/assets }\end{array}$ \\
\hline Livestock & $\begin{array}{l}\text { DHS (2012), UNDP (2010), Bishai et al. } \\
(2005)\end{array}$ & $\begin{array}{l}\text { Household wealth accumulated in } \\
\text { durables/assets, may secure basic } \\
\text { nutritional needs }\end{array}$ \\
\hline $\begin{array}{l}\text { Education/ } \\
\text { schooling }\end{array}$ & $\begin{array}{l}\text { Qi and Wu (2014), Échevin (2013), DHS } \\
\text { (2012), Sahn and Stifel (2003), UNDP } \\
\text { (2010), Battiston et al. (2013), Moser } \\
\text { and Felton (2007), Montgomery et al. } \\
\text { (2000) }\end{array}$ & $\begin{array}{l}\text { Human capital, increased } \\
\text { competitiveness on labour market, } \\
\text { increased health knowledge }\end{array}$ \\
\hline Employment & $\begin{array}{l}\text { DHS (2012), Wright (2008), de Kruijk } \\
\text { and Rutten (2007), Klasen (2000), } \\
\text { Montgomery et al. (2000) }\end{array}$ & $\begin{array}{l}\text { Income source and basis for self-respect } \\
\text { and fulfillment }\end{array}$ \\
\hline Food/hunger & $\begin{array}{l}\text { Qi and Wu (2014), Alkire and Foster } \\
\text { (2011), de Kruijk and Rutten (2007) }\end{array}$ & \\
\hline
\end{tabular}

The table is based on a comprehensive literature search. The electronic databases MEDLINE, social sciences citation index (SSCI), applied social sciences index and abstracts (ASSIA), global health, and Proquest dissertations and theses were searched (last update: July 2014). Additional relevant studies were identified through back referencing. Relevant grey literature was retrieved by screening the databases of UNAIDS, WHO, and the World Bank 
dimension is housing quality which may relate to hygiene and general health outcomes (Rutstein and Johnson 2004; Klasen 2000). Secondly, ownership of assets can have several welfare implications: Household assets can serve as a security buffer against economic shocks (Zimmerman and Carter 2003), livestock ownership can secure nutritional needs (Cohen and Saisana 2014), and a means of transport can translate into improved medical care and higher participation in social life. The last dimension is human capital which includes nutritional health, schooling, educational attainment, and employment; all of which have a range of positive externalities such as health-relevant knowledge, potential for income generation, as well as providing a source of self-respect and fulfilment (Sen 1993).

There are four types of aggregating individual indicators into a poverty scale. A first way assigns equal weights to each individual indicator such as in the HDI (for a critique, see Ravallion 2011; Filmer and Pritchett 2001). Alternatively, weights can be based on expert opinions and ethical deliberations of policy makers (OPHI 2013; for a critique, see Cohen and Saisana 2014). Thirdly, weights can be defined through participatory approaches and assigned according to priority patterns of the population of interest (Wright and Noble 2007; Noble et al. 2004; Barnes and Wright 2012). Lastly, scholars have used statistical procedures such as factor analysis or principal component analysis and assign weights based on correlation structures between a range of individual poverty indicators (Shaffer 2013; Sahn and Stifel 2003; Filmer and Pritchett 2001).

This paper aligns with the statistical approach for aggregating individual indicators from Table 1 into a composite poverty index. ${ }^{2}$ It is hereby assumed that each of these indicators reflects an underlying and unobserved variable that denotes household poverty. The index is designed to maximise discrimination between poorer and wealthier households. This is achieved by assigning higher weights to those poverty items that display more variation across households. In other words, assuming that every household owns a telephone, the item would be given a weight of zero as it would not adequately distinguish between worse and better off households. In the same vein, if no household were to own a car, the weight would again turn zero. Following this, each individual indicator is first assigned a specific and distinct weight before indicators are then summed up. The procedure yields a continuous scale in which higher scale scores denote a higher level of household poverty. Factor loadings for household assets and quality of housing will therefore be negative considering that possession or access decreases severity of poverty. The above process can be represented in the following equation:

$$
\mathrm{P}_{\mathrm{i}}=\mathrm{y}_{1} \mathrm{p}_{\mathrm{i} 1}+\cdots+\mathrm{y}_{\mathrm{k}} \mathrm{p}_{\mathrm{ik}}+\delta \mathrm{i}
$$

where $\mathrm{P}_{\mathrm{i}}$ denotes the poverty scale score, $\mathrm{p}_{\mathrm{ik}}$ the respective poverty indicators, $\mathrm{y}_{\mathrm{k}}$ the weights (factor loadings) for each indicators and $\delta_{\mathrm{i}}$ a stochastic error term (Sahn and Stifel 2003).

\subsection{Analyses}

Statistical analysis was done in three steps. First, exploratory factor analysis (EFA) was used in order to explore whether data was loading on a single or multiple factors and to eliminate irrelevant individual indicators. Screeplots and Eigenvalues were inspected for selecting factors (see Field 2009). An Eigenvalue indicates the amount of variance that a factor explains in a set of observed variables. In a screeplot variance is plotted against the

\footnotetext{
${ }^{2}$ While we refer to our composite measure as 'poverty index' throughout this paper, the index is designed to include a range of concepts including standard of living, quality of live, and wellbeing.
} 
number of principal components and serves to visually assess which factors explain most of the variability in the variance in the data. Consequently, items are assessed according to their factor loading. A factor loading reflects the strength of association of an individual variable with the underlying factor. Following Costello and Osborne (2005), we use a factor loading of 0.3 and above as orientation. Internal consistency was first assessed for items in the full sample and then for the urban and rural samples separately.

Second, following McKenzie (2003), kernel-density estimates for the poverty index were examined whereby a roughly normal distribution would suggest that 'clustering' or 'clumping' is unlikely That is, asset ownership and achievements should be independent from whether a respondent belongs to a certain geographical area or sub-population (i.e. cluster) Tests for normality were conducted using the Shapiro-Wilk-test.

A third step introduced structural equation modelling (SEM). Goodness of fit and internal consistency of the proposed measurement model was examined. Multiple-group comparisons in SEM were utilized for testing potential differences in the proposed measurement model across groups (Steenkamp and Baumgartner 1998). In this process, measurement invariance of the proposed poverty framework was assessed across groups, in this case urban and rural households. Invariance of the poverty measurement model is gradually increased and the fit of each subsequent model assessed (Steenkamp and Baumgartner 1998). At first, configural invariance is introduced, which requires the item structure to be maintained (that is, the same set of indicators is aggregated), but allows different loadings on each item (Acock 2013). Configural invariance can thereby assess whether poverty has the same meaning across groups or whether some items reflect social status in one society while they are less important in another society. Secondly, metric invariance is tested by constraining factor loadings to be invariant across groups. If factor loadings vary by sub-group, indicator weights are different for each group. In consequence, scale scores are based on different mathematical procedures; poverty rankings can therefore not be meaningfully compared across the full sample (Steenkamp and Baumgartner 1998; Meredith 1993). Thirdly, scalar invariance is tested, whereby intercepts of the underlying items are constrained to be equal across groups. If scalar invariance cannot be confirmed, it is possible that the design of the composite measure is biased against one of the groups and that observed poverty values differ systematically from latent poverty values. Model fit was assessed for each of the above three steps (Steenkamp and Baumgartner 1998; Meredith 1993). For this purpose, we used the Chi square goodness-of-fit test, the comparative fit index (CFI), the root mean error of approximation (RMSEA), and the standardized root mean square residual (SRMR). Conventional cut-offs indicating a good model fit require the values of CFI to be over 0.95 (and lower than 0.05 for RMSEA and SRMR. A CFI of 0.90 and RMSEA/SRMR of 0.08 may still be considered as a reasonable fit (see Schreiber et al. 2006; Hu and Bentler 1999). Poor fit would suggest that a single composite poverty index may be less valid and reliable for measuring household poverty across rural and urban sites within South Africa.

\section{Results}

\subsection{Descriptive Statistics}

$52 \%$ of households were located in urban and $48 \%$ in rural locations. Urban and rural interviewees were largely similar in terms of gender (female: $90 \%$ in rural, $87 \%$ in urban households), age (average of 45.2 years in rural, 43.2 years in urban households), and ethnic 
Table 2 Household poverty in urban and rural Kwa-Zulu Natal

Urban

Continuous variables

Number of children not attending school

Ratio: children attending to children not attending school

М 0.94

Overcrowding: ratio household members per room

Categorical variables

Hunger
Never
Seldom
Sometime
Often

Education

No schooling

Primary school

Secondary school

Matric

University

Employment

Permanent

Temporary

Unemployed

Binary variables

Meal with meat

Computer

TV

Radio

Refrigerator

Drinking source

Safe water

Washing machine

Electricity

Cooking

Heating

Lighting

Toilet

Floor

Wall

Dwelling

Phone

Car

Bicycle

Motorcycle

Cattle or sheep

Donkey or horse
M 1.56

M 5.08

M 2.12

M 3.50

$65.2 \%$

$54.4 \%$

$17.6 \%$

$19.6 \%$

$15.0 \%$

$25.0 \%$

$2.2 \%$

$1.0 \%$

$2.3 \%$

$36.7 \%$

$15.7 \%$

$37.4 \%$

$54.2 \%$

$17.7 \%$

$26.2 \%$

$7.5 \%$

$1.6 \%$

$0.7 \%$

$17.9 \%$

$7.3 \%$

$15.2 \%$

$13.5 \%$

$67.0 \%$

$79.2 \%$

$90.9 \%$

$65.4 \%$

$10.4 \%$

$2.4 \%$

$90.0 \%$

$38.1 \%$

$88.1 \%$

$62.6 \%$

$84.9 \%$

$29.9 \%$

$87.6 \%$

$26.9 \%$

$98.6 \%$

$82.0 \%$

$9.5 \%$

$0.3 \%$

$94.5 \%$

$9.9 \%$

$98.9 \%$

$6.6 \%$

$61.8 \%$

$1.8 \%$

$93.6 \%$

$6.9 \%$

$84.1 \%$

$2.1 \%$

$97.0 \%$

$93.5 \%$

$71.6 \%$

$67.5 \%$

$73.4 \%$

$63.3 \%$

$96.1 \%$

$93.2 \%$

$11.5 \%$

$12.3 \%$

$5.5 \%$

$5.9 \%$

$0.9 \%$

$0.2 \%$

$0.6 \%$

$11.6 \%$

$0.5 \%$

$0.8 \%$ 
Table 2 continued

\begin{tabular}{lll}
\hline & Urban & Rural \\
\hline $\mathrm{N}$ & 1279 & 1197 \\
\hline
\end{tabular}

Means displayed for continuous variables. For categorical variables, cells display the distribution of each category. For binary variables, each cell displays the percentage of households who indicate possession of item

origin (94\% Zulu in urban, $98 \%$ in rural households) of interviewed caregivers. Likewise, the structural composition of households (in terms of breadwinning and caregiving) was fairly similar: the average age of all household members was 23.5 years in urban and 18.0 years in rural households and the percentage of household members $>60$ years was $2.5 \%$ in urban and $4.1 \%$ in rural households. Table 2 displays all individual poverty indicators, stratified by urban and rural residency. Ownership of most assets is significantly higher in urban locations. Similarly, urban respondents appear significantly less food-insecure and have higher levels of education. In addition, unemployment is less prevalent in urban households, but could conceivably reflect labour migration to urban centres (Posel et al. 2006). In contrast, possession of livestock is higher in rural areas which may well be indicative of agricultural productivity, self-subsistence, income generation, as well as high property crime and limited space in urban areas (Batana 2013; Booysen et al. 2008). Further, while sanitation and building material appear more sophisticated in urban households, overcrowding-defined as the number of people sleeping in one room-is significantly higher in urban households. Importantly for intergenerational poverty, the average number of children who dropped out or are currently not attending school is significantly higher in urban areas.

\subsection{Exploratory Factor Analysis}

EFA initially included all items listed in Table 1. Inspection of screeplots and Eigenvalues suggested a single-factor solution (see Fig. 1). The first factor had an Eigenvalue of 6.47 and appeared to be the only strong factor, explaining $75.6 \%$ of the variance in the 23 poverty items.

Table 3 displays factor loadings for each individual item. Looking at the results of the EFA for the full sample, most items had loadings $>0.3$. After removing items with particularly low

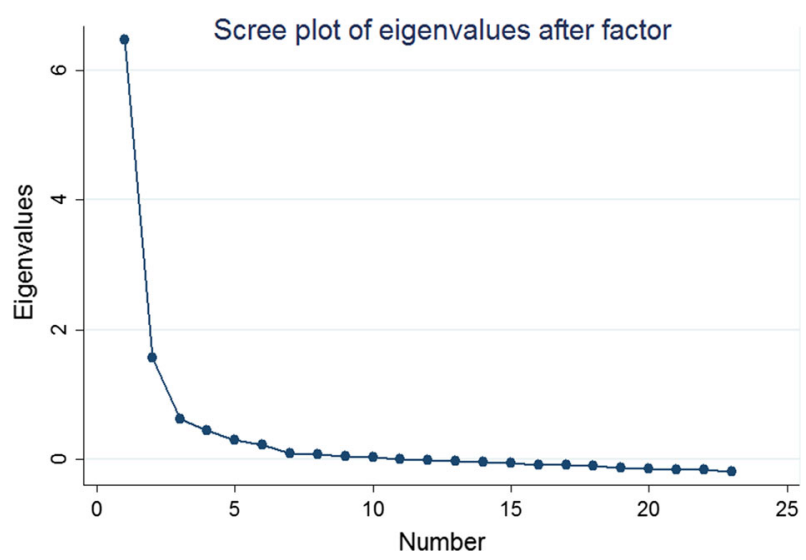

Fig. 1 Exploratory factor analysis: scree plot 
factor loadings (floor quality, overcrowding, possession of phone, livestock, car/bike, washing machine) the poverty scale had high internal reliability, with Cronbach's $\alpha=0.86$.

We then examined factor loadings for the urban and rural sub-samples separately. This showed that factor loadings varied considerably between the sub-samples. While some indicators appear important and are thus assigned a higher weight in one setting, they become less relevant in the other (see Vyas and Kumaranayake 2006). For instance, ownership of a vehicle appears to be indicative of which rural households are better off than others, whereas it does not show comparable importance in urban settings, likely reflecting better access to public transport, closer services and therefore lower need for private transport. Likewise, household overcrowding and possession of livestock do not reliably demarcate poverty status in urban settings. In contrast, possession of a washing machine shows low factor loadings for rural households, likely because only a negligible part of rural households own a washing machine $(0.3 \%)$.

Table 3 Summary of single-factor exploratory factor analysis

\begin{tabular}{|c|c|c|c|}
\hline Item & Full sample $(\mathrm{n}=2353)$ & Rural sample $(\mathrm{n}=1212)$ & Urban sample $(\mathrm{n}=1140)$ \\
\hline Hunger & 0.25 & 0.36 & 0.21 \\
\hline Refrigerator & -0.74 & -0.59 & -0.64 \\
\hline Phone & -0.15 & -0.15 & -0.18 \\
\hline Computer & -0.26 & -0.20 & -0.24 \\
\hline Transport & -0.18 & -0.44 & -0.28 \\
\hline Meat & -0.42 & -0.36 & -0.25 \\
\hline TV & -0.71 & -0.55 & -0.68 \\
\hline Radio & -0.45 & -0.36 & -0.44 \\
\hline Drinking source & -0.67 & -0.31 & -0.58 \\
\hline Safe water & -0.27 & -0.01 & $-\mathbf{0 . 1 3}$ \\
\hline Washing machine & -0.28 & -0.11 & -0.22 \\
\hline Electricity & -0.90 & -0.58 & -0.72 \\
\hline Cooking & -0.87 & -0.54 & -0.16 \\
\hline Heating & -0.67 & -0.39 & -0.30 \\
\hline Lighting & -0.80 & -0.61 & -0.68 \\
\hline Toilet & -0.91 & -0.24 & -0.41 \\
\hline Floor & -0.18 & -0.25 & -0.20 \\
\hline Wall & -0.32 & -0.54 & -0.68 \\
\hline Dwelling & -0.39 & -0.55 & -0.66 \\
\hline Overcrowding & 0.04 & 0.30 & 0.02 \\
\hline Livestock & 0.14 & -0.14 & $-\mathbf{0 . 0 7}$ \\
\hline Education & -0.61 & -0.36 & -0.21 \\
\hline Employment & -0.23 & -0.25 & -0.10 \\
\hline Eigenvalues & 6.47 & 3.56 & 4.01 \\
\hline$\%$ of variance & 75.6 & 67.5 & 60.8 \\
\hline$\alpha^{\mathrm{a}}$ & 0.86 & 0.70 & 0.72 \\
\hline
\end{tabular}

Information on children's schooling was not available for all sampled households. The variable was thus excluded from EFA so as to keep the size of the sample

a Excluding items with factor loadings low factor loadings (highlighted in bold and italics) 

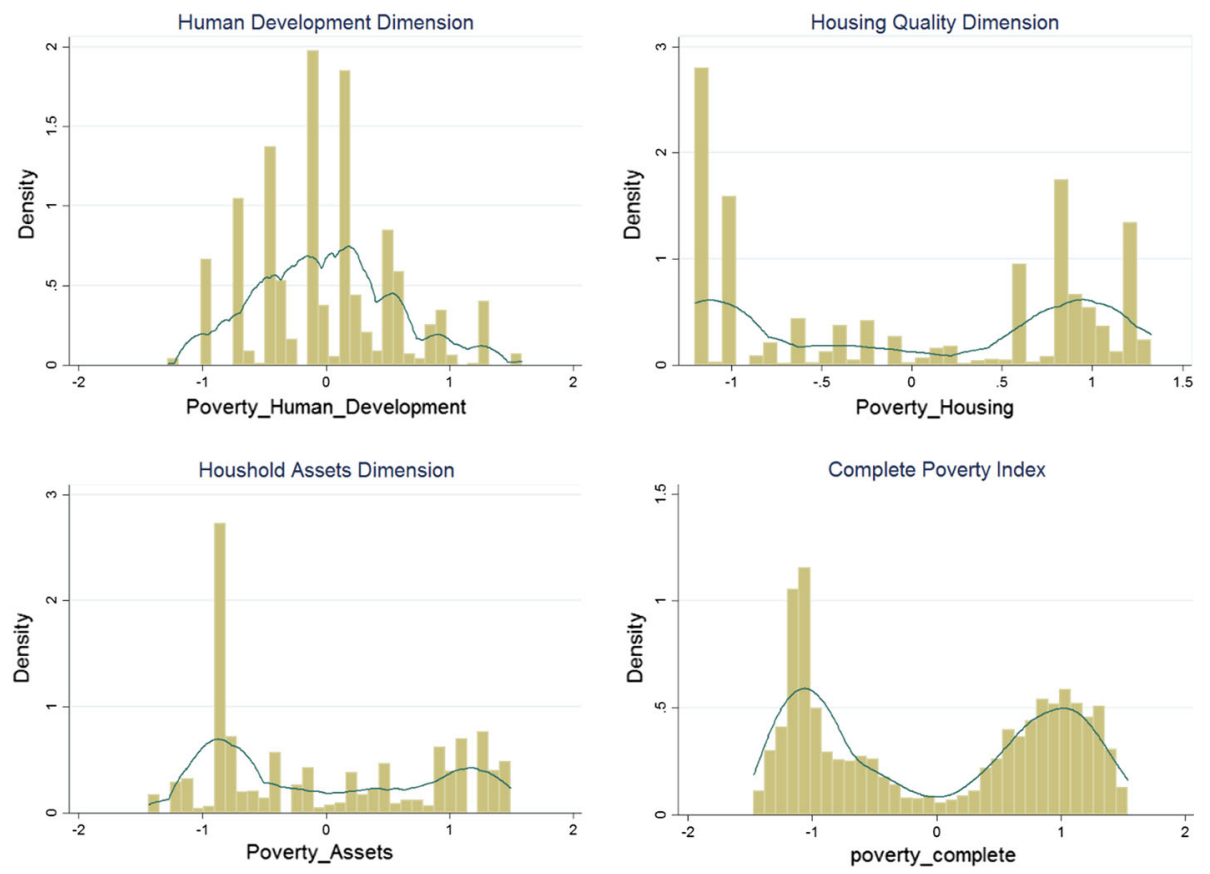

Fig. 2 Histograms and kernel densities for the distribution of poverty indicators

\subsection{Distribution of Poverty}

Figure 2 displays histograms and kernel-density estimates for the distribution of different composite poverty indicators across urban and rural location. Three sub-indices were created to reflect three dimensions: (1) human capital/human development (including education, schooling, employment, and hunger), (2) housing quality, and (3) asset ownership. The last graph in Fig. 2 examines the complete composite poverty index. Following McKenzie (2003), the non-normal distribution of values on the separate dimensions and composite index suggest the presence of 'clumping'. After displaying histograms for urban and rural subgroups separately, it becomes apparent that the two peaks in each distribution coincide with the two subgroups. That is, respondents appear to be clumped together in urban and rural groups and patterns of asset ownership and achievements are distinct from each other. Utilizing the Shapiro-Wilk-test, we rejected the null hypothesis that any of the above indices is normally distributed $(p<0.001)$. Further, we employ a rigorous statistical procedure for examining multimodality in the distribution of the complete composite poverty index. Utilizing Silverman's (1981) non-parametric test, we test whether the above kernel density distribution has two (or more) modes against the null hypothesis of a single mode. ${ }^{3}$ We use 500 bootstrap replications for estimating the critical bandwidth of the distribution. Results of the Silverman test reject unimodality with a confidence level of $p<0.01$. We cannot reject the null hypothesis of two modes in favour of three modes $(p=0.12)$, suggesting that the distribution has indeed two peaks that reflect the urban and rural samples.

\footnotetext{
${ }^{3}$ For a similar approach, see: Vollmer et al. (2013a, b, c).
} 
Table 4 Measurement model of the poverty index

\begin{tabular}{|c|c|c|}
\hline & Standardized & Unstandardized \\
\hline \multicolumn{3}{|l|}{ Measurement model } \\
\hline Hunger & $0.19 * * *$ & 1 (fixed) \\
\hline Meat & $-0.38 * * *$ & $-0.99 * * *$ \\
\hline Overcrowding & $0.04 * *$ & $1.96^{* *}$ \\
\hline Computer & $-0.22 * * *$ & $-0.33 * * *$ \\
\hline Transport & $-0.11 * * *$ & $-0.24 * * *$ \\
\hline TV & $-0.67 * * *$ & $-2.00 * * *$ \\
\hline Radio & $-0.41 * * *$ & $-1.09 * * *$ \\
\hline Refrigerator & $-0.70 * * *$ & $-2.13 * * *$ \\
\hline Drinking source & $-0.69 * * *$ & $-2.10^{* * * *}$ \\
\hline Electricity & $-0.90 * * *$ & $-2.80 * * *$ \\
\hline Cooking & $-0.91 * * *$ & $-2.84 * * *$ \\
\hline Heating & $-0.69 * * *$ & $-2.00 * * *$ \\
\hline Lighting & $-0.92 * * *$ & $-2.85^{* * *}$ \\
\hline Toilet & $-0.82 * * *$ & $-2.50 * * *$ \\
\hline Floor & $-0.14 * * *$ & $-0.19 * * *$ \\
\hline Wall & $-0.20 * * *$ & $-0.57 * * *$ \\
\hline Dwelling & $-0.27 * * *$ & $-0.77 * * *$ \\
\hline Education & $-0.60 * * *$ & $-3.78 * * *$ \\
\hline Employment & $-0.21 * * *$ & $-0.90 * * *$ \\
\hline \multicolumn{3}{|l|}{ Covariances } \\
\hline Error.meat with error.hunger & $-0.24 * * *$ & $-0.08 * * *$ \\
\hline Error.electricity with error.lighting & $0.64 * * *$ & $0.03 * * *$ \\
\hline Error.floor with error.dwelling & $0.05 * * *$ & $0.01 * * *$ \\
\hline Error.wall with error.dwelling & $0.72 * * *$ & $0.14 * * *$ \\
\hline Error.education with error.employment & $0.13 * * *$ & $0.07 *$ \\
\hline \multicolumn{3}{|l|}{ Goodness of fit } \\
\hline$\chi^{2}$ & $2455.108 * * *$ & \\
\hline CFI & 0.83 & \\
\hline RMSEA & 0.08 & \\
\hline SRMR & 0.90 & \\
\hline
\end{tabular}

\subsection{Structural Equation Model: Multiple Group Comparison}

When fitting the above poverty index in a structural equation model, the four items of: access to a safe water source, possession of a phone, possession of livestock, and possession of a washing machine were removed as showing low factor loadings for both rural and urban groups in EFA. Introducing the structural equation model, goodness of fit of the original model proved low. To improve model fit, modification indices were inspected to inform possible changes to the model. Error terms were correlated based on substantial modification index values and conceptual logic (see Schreiber et al. 2006). This included correlated errors for the item pairs of wall and dwelling type, floor and dwelling type, hunger and meat, electricity and lighting, and education and employment. This considerably improved the fit of the measurement model (see Table 4) with CFI of 0.90. 
Turning to multiple group comparisons, the average level of poverty was found to be substantially higher in the rural sample (M 0.14, SD 0.07) as compared to the urban sample (M -0.15 , SD 0.06) (note: higher scale scores representing higher poverty). Following this, the procedural steps proposed by Steenkamp and Baumgartner (1998) were introduced. Table 5 displays the model fit for all three types of invariance tests and reveals that configural invariance - the model with the fewest constraints - had a CFI of 0.83 and thus did not display acceptable fit. Model fit became again weaker with every additional constraint on measurement invariance (CFI 0.79 for metric invariance and CFI 0.0 for scalar invariance). This finding points to a difference in the meaning of poverty between rural and urban households and to variations in the importance of specific poverty items across locations. Hence, validity and adequacy of the suggested poverty indicator could not be confirmed across the two populations.

Table 6 displays multiple-group comparisons for the model with the most acceptable fit. In this model, constraints are put on the number and kind of indicators used, but loadings are not required to be equal. The results strongly suggest that each sub-population assigns different importance to respective items. Generally speaking, asset ownership, sanitation, and energy appear to be of higher relevance in urban households, whereas employment and education turn out to be more emphasised in rural households. Overcrowding is found to be inadequate for measuring household poverty status in urban areas, as the item loading is non-significant for this sub-group.

\section{Discussion and Concluding Remarks}

We set out to test the validity of a composite poverty index across urban and rural locations within an ethnically homogenous population. The analysis revealed substantial variations in the meaning and conceptualisation of poverty among urban and rural respondents. Factor loadings for individual poverty indicators were found to differ significantly between populations. A considerable number of poverty items such as household overcrowding, transportation, or employment could distinguish adequately between poorer and wealthier households in one area, but were found to have little relevance to socioeconomic status in the other area. In addition, the analysis found indication of 'clumping' effects in the distribution of observed poverty levels - pointing to different patterns of asset ownership and housing quality in urban and rural populations. Equivalence in the measurement model could not be confirmed across groups. Poverty rankings along the constructed poverty scale would thus be subject to measurement error.

The measurement approach we employed in this paper was similar to composite poverty measures commonly used in literature on household poverty and development. However, as revealed by this analysis, the poverty index did not show cross-geographical validity, even in an ethnically homogenous population. In other words, it appears that poverty

Table 5 Goodness-of-fit indices for original and modified model

\begin{tabular}{lllll}
\hline Model & $\chi^{2}$ & CFI & RMSEA & SRMR \\
\hline Configural invariance & $\begin{array}{l}2198.289 \\
p<0.001\end{array}$ & 0.83 & 0.07 & 0.06 \\
Metric invariance & $\begin{array}{l}2641.092 \\
p<0.001\end{array}$ & 0.79 & 0.08 & 0.09 \\
Scalar invariance & $\begin{array}{l}12,112.490 \\
p<0.001\end{array}$ & 0.00 & 0.17 & 0.30 \\
\hline
\end{tabular}


Table 6 Multiple-group SEM for urban and rural sub-populations

\begin{tabular}{|c|c|c|}
\hline & $\operatorname{Urban}(\mathrm{N}=1144)$ & Rural $(\mathrm{N}=1212)$ \\
\hline \multicolumn{3}{|l|}{ Measurement model } \\
\hline Hunger & $0.21 * * *$ & $0.34 * * *$ \\
\hline Meat & $-0.27 * * *$ & $-0.35 * * *$ \\
\hline Overcrowding & 0.01 & $0.28 * * *$ \\
\hline Computer & $-0.20 * * *$ & $-0.20 * * *$ \\
\hline Transport & $-0.24 * * *$ & $-0.46 * * *$ \\
\hline TV & $-0.76^{* * *}$ & $-0.57 * * *$ \\
\hline Radio & $-0.49 * * *$ & $-0.38 * * *$ \\
\hline Refrigerator & $-0.71 * * *$ & $-0.62 * * *$ \\
\hline Drinking source & $-1.11 * * *$ & $-0.32 * * *$ \\
\hline Electricity & $-0.65^{* * *}$ & $-0.51 * * *$ \\
\hline Cooking & $-0.08 * * *$ & $-0.54 * * *$ \\
\hline Heating & $-0.84 * * *$ & $-0.40 * * *$ \\
\hline Lighting & $-0.60 * * *$ & $-0.54 * * *$ \\
\hline Toilet & $-0.33 * * *$ & $-0.23 * * *$ \\
\hline Floor & $-0.17 * * *$ & $-0.23 * * *$ \\
\hline Wall & $-0.56^{* * *}$ & $-0.43 * * *$ \\
\hline Dwelling & $-0.53 * * *$ & $-0.45^{* * *}$ \\
\hline Education & $-0.18 * * *$ & $-0.37 * * *$ \\
\hline Employment & $-0.09 * * *$ & $-0.27 * * *$ \\
\hline \multicolumn{3}{|l|}{ Covariances } \\
\hline Error.meat with error.hunger & $-0.17 * * *$ & $-0.22 * * *$ \\
\hline Error.electricity with error.lighting & $0.82 * * *$ & $0.63 * * *$ \\
\hline Error.floor with error.dwelling & 0.04 & $0.05 *$ \\
\hline Error.wall with error.dwelling & $0.68 * * *$ & $0.64 * * *$ \\
\hline Error.education with error.employment & $0.19 * * *$ & $0.07 *$ \\
\hline \multicolumn{3}{|l|}{ Goodness of fit } \\
\hline$\chi^{2}$ & $2198.29 * * *$ & \\
\hline CFI & 0.83 & \\
\hline RMSEA & 0.07 & \\
\hline SRMR & 0.06 & \\
\hline
\end{tabular}

$* p<0.05 ; * * p<0.01 ; * * * p<0.001$

manifests differently and is perceived differently in urban and rural communities within one province in South Africa. The value that each population assigns to a certain indicator defines the magnitude of its weight for statistical aggregation. Yet, if weights vary in urban and rural populations, scale scores are derived from different mathematical procedures. Comparability becomes invalid. This finding is crucial as previous rankings and comparisons of household poverty levels across South Africa (or even across KwaZulu-Natal) could thus be less reliable than thought.

According to the composite index, household poverty and deprivation appeared more pronounced in rural areas. This is in line with a range of prior studies (Batana 2013; Bérenger et al. 2013; Rutstein and Johnson 2004). Tendencies were somewhat similar in descriptive statistics of this analysis, but a number of essential indicators such as 
overcrowding and educational attainment portrayed rural households on average as 'better off'. Therefore, while the finding of higher rural deprivation may indeed have some validity, these findings suggest that the conceptualisation of conventionally used poverty indices and the selection of individual indicators may be biased against rural households (Booysen et al. 2007, 2008). A range of items such as electricity, sewerage, and access to piped water reflect available infrastructure and public service provision rather than reliably measuring a range of differences in poverty levels (Harttgen et al. 2013). Moreover, other indicators such as land ownership or agricultural assets that are presumably more strongly valued in rural areas, are usually absent in conventional composite poverty measurements (Batana 2013; Vyas and Kumaranayake 2006). That is, poverty levels in rural families may indeed be higher, but the design of indices may also be prone to overestimating these differences.

This study has a number of limitations. Whilst an analysis like the one that we conducted here can test the validity of a composite poverty index within the context of South Africa, it would be interesting also to examine its performance across countries and over time. As Harttgen et al. (2013) describe, certain assets can become more accessible and prevalent over time (e.g. TVs and phones) and might thus become less adequate for classifying wealthier and poorer households. A 'standard size' poverty index would be subject to measurement bias as assigned weights would differ between one time point and the other (Vyas and Kumaranayake 2006).

Some more limitations are noteworthy that are inherent to all composite poverty measurements. A fist limitation lies in the binary nature of poverty indicators. That is, the aggregated index captures ownership of a certain asset, but not necessarily their quality, functionality, and possible depreciation over time (Harttgen et al. 2013; Falkingham and Namazie 2002). More importantly, most poverty indicators were measured at a household rather than individual level. Hence, there was no information on potential intra-household inequalities such as in education or nutrition. Specifically, there might be significant differences in resource distributions between female and male household members that could point to important gender gaps in a society (Harttgen et al. 2013), but that the present analysis could not detect. Further, we have tested validity in a very specific population and cannot claim generalizability of our findings.

This analysis hopes to contribute to the ongoing debate, as we strive towards the most effective means of both measurement and reduction of poverty in the developing world. Although great strides have been made in developing composite policy indices, further refinement may be required in order to identify whether these indices can serve as an adequate measurement tool for identifying the poorest and most deprived households, both within and across countries.

Acknowledgements The Young Carers study was funded by the Economic and Social Research Council (UK), the National Research Foundation (SA), the Health Economics and HIV and AIDS Research Division (HEARD) at the University of KwaZulu-Natal, the National Department of Social Development (South Africa), the Claude Leon Foundation, and the John Fell Fund. Professor Cluver was supported by funding from the European Research Council under the European Union's Seventh Framework Programme (FP7/ 2007-2013)/ERC Grant Agreement No. 313421. Ethical approval for the study was granted by the Research Ethics Committees of the University of Oxford, the University of Cape Town, the University of KwaZuluNatal, and the University of the Witwatersrand as well as the Departments of Health and Education from KwaZulu-Natal province. We thank all the participants and their families who took part in this research. Lastly, the authors wish to thank Dr. Thees Spreckelsen for valuable statistical advice.

Open Access This article is distributed under the terms of the Creative Commons Attribution 4.0 International License (http://creativecommons.org/licenses/by/4.0/), which permits unrestricted use, distribution, and reproduction in any medium, provided you give appropriate credit to the original author(s) and the source, provide a link to the Creative Commons license, and indicate if changes were made. 


\section{Appendix: Poverty Indicators and Codings}

\begin{tabular}{|c|c|c|}
\hline Indicator & Coding & $\begin{array}{l}\text { Measurement } \\
\text { level }\end{array}$ \\
\hline $\begin{array}{l}\text { Possession of a bicycle, car, } \\
\text { motorcycle }=>\text { collapsed into } \\
\text { one variable transport }\end{array}$ & $\begin{array}{l}\text { Yes }=1 \\
\text { No }=0\end{array}$ & Household \\
\hline Possession of a refrigerator & $\begin{array}{l}\text { Yes }=1 \\
\text { No }=0\end{array}$ & Household \\
\hline Possession of a telephone & $\begin{array}{l}\text { Yes }=1 \\
\text { No }=0\end{array}$ & Household \\
\hline Possession of a TV & $\begin{array}{l}\text { Yes }=1 \\
\text { No }=0\end{array}$ & Household \\
\hline Possession of a radio & $\begin{array}{l}\text { Yes }=1 \\
\text { No }=0\end{array}$ & Household \\
\hline Possession of a computer & $\begin{array}{l}\text { Yes }=1 \\
\text { No }=0\end{array}$ & Household \\
\hline $\begin{array}{l}\text { Possession of sheep/cattle, donkey/ } \\
\text { horse }=>\text { collapsed into one } \\
\text { variable animals }\end{array}$ & $\begin{array}{l}\text { Yes }=1 \\
\text { No }=0\end{array}$ & Household \\
\hline Meal with meat once a week & $\begin{array}{l}\text { Yes }=1 \\
\text { No }=0\end{array}$ & $\begin{array}{l}\text { Individual (primary } \\
\text { caregiver) }\end{array}$ \\
\hline $\begin{array}{l}\text { Hunger, i.e. people in household } \\
\text { who are hungry }\end{array}$ & $\begin{array}{l}\text { Ordinal variable } \\
\text { Never }=1 \\
\text { Seldom }=2 \\
\text { Sometimes }=3 \\
\text { Often }=4\end{array}$ & $\begin{array}{l}\text { Household/ } \\
\text { Individual }\end{array}$ \\
\hline Electricity in the house & $\begin{array}{l}\text { Yes }=1 \\
\text { No }=0\end{array}$ & Household \\
\hline Main source of drinking water & $\begin{array}{l}\text { Original categories } \\
\text { 1. Piped water (tap) in dwelling } \\
\text { 2. Piped water (tap) in site/yard } \\
\text { 3. Bottled water } \\
\text { 4. Public tap } \\
\text { 5. Water carrier/tanker } \\
\text { 6. Borehole/well } \\
\text { 7. Dam/river/stream/spring } \\
\text { 8. Rain-water tank } \\
\text { 9. Neighbour's tap } \\
\text { 10. Other } \\
=>\text { Collapsed into a binary variable: access to } \\
\text { piped water }(1 . / 2 .)=1 \text { remaining categories }=0 \\
\text { Category "other" recoded manually (see Sahn and } \\
\text { Stifel } 2003, \text { p. 469) }\end{array}$ & Household \\
\hline Is the water from that source safe? & $\begin{array}{l}\text { Yes }=1 \\
\text { No }=0\end{array}$ & Household \\
\hline Toilet type & $\begin{array}{l}\text { Original categories } \\
\text { 1. Flush toilet (own) } \\
\text { 2. Flush toilet (shared) } \\
\text { 3. Bucket latrine } \\
\text { 4. Pit latrine } \\
\text { 5. No facility/bush/field } \\
\text { 6. Other } \\
=>\text { Collapsed into a binary variable: flush } \\
\text { toilet = 1, remaining categories = } 0 \\
\text { Category "other" recoded manually (see Sahn and } \\
\text { Stifel } 2003 \text {, p. } 469 ; \text { Filmer and Pritchett } 2001 \text {, } \\
\text { p. } 117 \text { ) }\end{array}$ & Household \\
\hline
\end{tabular}




\begin{tabular}{|c|c|c|}
\hline Indicator & Coding & $\begin{array}{l}\text { Measurement } \\
\text { level }\end{array}$ \\
\hline $\begin{array}{l}\text { Material of the } \\
\text { floor }\end{array}$ & $\begin{array}{l}\text { Original categories } \\
\text { 1. Earth/sand/dung } \\
\text { 2. Bare wood planks } \\
\text { 3. Cement } \\
\text { 4. Vinyl } \\
\text { 5. Carpet } \\
\text { 6. Ceramic tiles } \\
\text { 7. Parquet or polished wood } \\
\text { 8. Other } \\
\text { = Collapsed into a binary variable: } \\
\text { "smart" floor (no dirt,sand, dung or } \\
\text { wood) = 1, remaining categories =0 } \\
\text { Category "other" recoded manually (see } \\
\text { Booysen et al. 2008) }\end{array}$ & Household \\
\hline Material of the wall & $\begin{array}{l}\text { Original categories } \\
\text { 1. Plastic/cardboard } \\
\text { 2. Mud } \\
\text { 3. Mud and cement } \\
\text { 4. Corrugated iron/zink } \\
\text { 5. Prefab } \\
\text { 6. Bare brick } \\
\text { 7. Cement block } \\
\text { 8. Plaster/finished } \\
\text { 9. Wooden planks } \\
\text { 10. Other } \\
=>\text { Collapsed into a binary variable: } \\
\text { cement/plastered/prefab wall }=1 \text {, } \\
\text { remaining categories }=0 \\
\text { Category "other" recoded manually }\end{array}$ & Household \\
\hline Dwelling type & $\begin{array}{l}\text { Original categories } \\
\text { 1. Dwelling/house or brick structure on a } \\
\text { separate stand/yard } \\
\text { 2. Town/cluster/semi-detached house } \\
\text { 3. Dwelling/house/flat/room in backyard } \\
\text { 4. Informal dwelling/shack in backyard } \\
\text { 5. Informal dwelling/shack not in backyard } \\
\text { 6. Room/flatlet on a property or a larger } \\
\text { dwelling } \\
\text { 7. Caravan/tent, other } \\
\text { 8. Other } \\
\text { => Collapsed into a binary variable: } \\
\text { formal housing (brick structure, } \\
\text { town/cluster/semi-detached house, house } \\
\text { on someone else's property, and } \\
\text { apartment rentals) = 1, informal housing } \\
\text { (shacks, caravans or tents, and traditional } \\
\text { huts made of mud, stone, or wattle) =0 } \\
\text { Category "other" recoded manually }\end{array}$ & Household \\
\hline
\end{tabular}


Indicator

Coding

Measurement

level

Main source of energy for heating

Original categories

Household

1. Electricity from mains

2. Electricity from generator

3. Gas

4. Paraffin

5. Wood

6. Coal

7. Candles

8. Animal dung

9. Solar energy

10. Other

$=>$ Collapsed into a binary variable:

electricity/gas $=1$, remaining categories $=0$

category "other" recoded manually (see Qi and Wu 2014, p. 94)

Main source of energy for cooking Original categories

Household

1. Electricity from mains

2. Electricity from generator

3. Gas

4. Paraffin

5. Wood

6. Coal

7. Candles

8. Animal dung

9. Solar energy

10. Other

$=>$ Collapsed into a binary variable:

electricity/gas $=1$, remaining categories $=0$

Category "other" recoded manually (see Qi and Wu 2014, p. 94; Cohen and Saisana 2014, p. 36)

Main source of energy for lighting

Original categories

1. Electricity from mains

Household

2. Electricity from generator

3. Gas

4. Paraffin

5. Wood

6. Coal

7. Candles

8. Animal dung

9. Solar energy

10. Other

$=>$ Collapsed into a binary variable:

electricity/gas $=1$, remaining categories $=0$

category "other" recoded manually (see Qi and Wu 2014, p. 94)

Schooling children

Three different variables

Number of children in school

Number of children not in school

Ratio: number of children in school/number of

children not in school per household

Household/

Individual (each

non-adult

household

member) 


\begin{tabular}{|c|c|c|}
\hline Indicator & Coding & $\begin{array}{l}\text { Measurement } \\
\text { level }\end{array}$ \\
\hline Education of primary caregiver & $\begin{array}{l}\text { Original categories } \\
\text { 1. No schooling } \\
\text { 2. Grade } \mathrm{R} / 0 \\
\text { 3. Grade } 1 / \text { sub A } \\
\text { 4. Grade } 3 / \text { standard } 1 \\
\text { 5. Grade } 4 / \text { standard } 2 \\
\text { 6. Grade } 5 / \text { standard } 3 \\
\text { 7. Grade } 6 / \text { standard } 4 \\
\text { 8. Grade } 7 / \text { standard } 5 \\
\text { 9. Grade } 8 / \text { standard } 6 \\
\text { 10. Grade } 9 / \text { standard } 7 \\
\text { 11. Grade } 10 / \text { standard } 8 \\
\text { 12. Grade } 11 / \text { standard } 9 \\
\text { 13. Certificate with less than grade } 12 / \text { standard } 10 \\
\text { 14. Diploma with less than grade } 12 / \text { standard } 10 \\
\text { 15. Grade } 12 / \text { standard } 10 \\
\text { 16. Certificate with grade } 12 / \text { standard } 10 \\
\text { 17. Diploma with grade } 12 / \text { standard } 10 \\
\text { 18. NTC I/NTC II/NTC III } \\
\text { 19. Bachelors degree } \\
\text { 20. Honours } \\
\text { 21. Higher degree masters, doctorate } \\
\text { 22. Other } \\
=>\text { Collapsed into ordinal variable } \\
\text { None }=1 \\
\text { Primary }=2 \\
\text { Secondary }=3 \\
\text { Matric }=4 \\
\text { University }=5\end{array}$ & $\begin{array}{l}\text { Individual (primary } \\
\text { caregiver) }\end{array}$ \\
\hline Employment & $\begin{array}{l}\text { Ordinal variable } \\
\text { No job }=0 \\
\text { Temporary employment }=1 \\
\text { Permanent employment }=2\end{array}$ & $\begin{array}{l}\text { Individual (primary } \\
\text { caregiver) }\end{array}$ \\
\hline
\end{tabular}

\section{References}

Acock, A. C. (2013). Discovering structural equation modeling using Stata. College Station, TX: StataCorp LP.

Alkire, S., Conconi, A., Robles, G., Roche, J. M., Santos, M. E., Seth, S., et al. (2016a). The global multidimensional poverty index (MPI): 5-year methodological note. OPHI Briefing No. 37. http:// www.ophi.org.uk/wp-content/uploads/MPI_Methodology_2010-2015_Jan2016.pdf. Accessed April 7, 2016.

Alkire, S., \& Foster, J. (2011). Counting and multidimensional poverty measurement. Journal of Public Economics, 95(7), 476-487.

Alkire, S., Jindra, C., Robles, G., \& Vaz, A. (2016b). Multidimensional poverty index: Brief methodological note and results. OPHI Briefing No. 42. http://www.ophi.org.uk/wp-content/uploads/MPI-2016-BriefMethodological-Note.pdf. Accessed September 20, 2016.

Alkire, S., \& Santos, M. E. (2014). measuring acute poverty in the developing world: Robustness and scope of the multidimensional poverty index. World Development, 59, 251-274.

Barnes, H., \& Wright, G. (2012). Defining child poverty in South Africa using the socially perceived necessities approach. In A. Minujin \& S. Nandy (Eds.), Global child poverty and well-being: Measurement, concepts, policy and action (pp. 135-155). Bristol: The Policy Press.

Batana, Y. M. (2013). Multidimensional measurement of poverty among women in sub-Saharan Africa. Social Indicators Research, 112(2), 337-362.

Battiston, D., Cruces, G., Lopez-Calva, L.P., Lugo, M.A., \& Santos, M.A. (2013). Income and Beyond: Multidimensional Poverty in Six Latin American Countries. Social Indicators Research, 112(2), 291-314. 
Bérenger, V., Deutsch, J., \& Silber, J. (2013). Durable goods, access to services and the derivation of an asset index: Comparing two methodologies and three countries. Economic Modelling, 35(3), 881-891.

Bishai, D., Waters, H., et al. (2005). The impact of vitamin A supplementation on mortality inequalities among children in Nepal. Health Policy Planing, 20, 60-66.

Booysen, F. L. R., Burger, R., Rand, G., Maltitz, M., \& Van der Berg, S. (2007). Trends in poverty and inequality in seven African countries. http://ideas.repec.org/p/lvl/pmmacr/200706.html. Accessed October 28, 2015.

Booysen, F. L. R., Van der Berg, S., Burger, R., Maltitz, M., \& Rand, G. (2008). Using an asset index to assess trends in poverty in seven sub-Saharan African countries. World Development, 36(6), 1113-1130.

Carter, M. R., \& Barrett, C. (2006). The economics of poverty traps and persistent poverty: An asset-based approach. Journal of Development Studies, 42(2), 178-199.

Chakraborty, N. M., Fry, K., Behl, R., \& Longfield, K. (2016). Simplified asset indices to measure wealth and equity in health programs: A reliability and validity analysis using survey data from 16 countries. Global Health: Science and Practice, 4(1), 141-154.

Cluver, L., Orkin, M., Boyes, M. E., Sherr, L., Makasi, D., \& Nikelo, J. (2013). Pathways from parental AIDS to child psychological, educational and sexual risk: Developing an empirically-based interactive theoretical model. Sociel Sciences and Medicine, 87, 185-193.

Cohen, A., \& Saisana, M. (2014). Quantifying the qualitative: Eliciting expert input to develop the multidimensional poverty assessment tool. Journal of Development Studies, 50(1), 35-50.

Costello, A. B., \& Osborne, J. W. (2005). Best practices in exploratory factor analysis: Four recommendations for getting the most from your analysis. Practical Assessessment. Research Evaluation, 10(7), $173-178$.

Daniels, R. C., Partridge, A., Kekana, D., \& Musundwa, S. (2013). Rural livelihoods in South Africa. SALDRU Working Paper No. 122/NIDS Discussion Paper, Cape Town.

Demographic and Health Survey (DHS). (2012). The DHS Wealth Index. Retrieved from http://dhsprogram. com/pubs/pdf/CR6/CR6.pdf. Accessed 01 Nov 2016.

de Kruijk, H., \& Rutten, M. (2007). Weighting Dimensions of Poverty based on Peoples Priorities: Constructing a Composite Poverty Index for the Maldives. IIDE Discussion Papers 20070801, Institue for International and Development Economics.

Douidich, M., Ezzrari, A., Van der Weide, R., \& Verme, P. (2015). Estimating quarterly poverty rates using labor force surveys: A primer. The World Bank Economic Review. doi:10.1093/wber/lhv062.

Échevin, D. (2013). Measuring vulnerability to asset-poverty in sub-Saharan Africa. World Development, 46, 211-222.

Falkingham, J., \& Namazie, C. (2002). Measuring health and poverty: A review of approaches to identifying the poor. DFID Health Systems Resource Center-Issue Paper. http://r4d.dfid.gov.uk/PDF/Outputs/ HOppsIssuesPaperFalkingham.pdf. Accessed April 19, 2016.

Ferreira, F. H. G., \& Lugo, M. A. (2013). Multidimensional poverty analysis: Looking for a middle ground. World Bank Research Observer, 28(2), 220-235.

Field, A. (2009). Discovering statistics using SPSS. London: Sage.

Filmer, D., \& Pritchett, L. H. (2001). Estimating wealth effects without expenditure data-Or tears: An application to educational enrollments in states of India. Demography, 38(1), 115-132.

Filmer, D., \& Scott, K. (2012). Assessing asset indices. Demography, 49(1), 359-392.

Harttgen, K., Klasen, S., \& Vollmer, S. (2013). An African growth miracle? Or: What do asset indices tell us about trends in economic performance? Review of Income and Wealth, 59, 37-61.

Hruschka, D. J., Gerkey, D., \& Hadley, C. (2015). Estimating the absolute wealth of households. Bulletin of the World Health Organization, 93(7), 483-490. doi:10.2471/BLT.14.147082.

Hu, L., \& Bentler, P. M. (1999). Cutoff criteria for fit indexes in covariance structure analysis: Conventional criteria versus new alternatives. Structural Equation Modeling, 6(1), 1-55.

Klasen, S. (2000). Measuring poverty and deprivation in South Africa. Review of Income and Wealth, 46(1), $33-58$.

McKenzie, D. (2003). Measuring inequality with asset indicators. BREAD Working Paper No. 042. http:// ibread.org/bread/system/files/bread_wpapers/042.pdf. Accessed April 19, 2016.

Meredith, W. (1993). Measuremnt invariance, factor analysis, and factorial invariance. Psychometrika, 58(4), 525-543.

Michelson, H., Muñiz, M., \& DeRosa, K. (2013). Measuring socio-economic status in the millennium villages: The role of asset index choice. The Journal of Development Studies, 49(7), 917-935.

Montgomery, M.R., Gragnolati, M., Burke, K.A., \& Paredes, E. (2000). Measuring living standards with proxy variables. Demography, 37(2), 155-174. 
Moser, C. O., \& Felton, A. (2007). The construction of an asset index measuring asset accumulation in Ecuador. In T. Addison, D. Hulme, \& R. Kanbu (Eds.), Poverty dynamics. Interdisciplinary perspectives (pp. 102-128). Oxford: Oxford University Press.

Noble, M., Ratcliffe, A., \& Wright, G. (2004). Conceptualizing, defining and measuring poverty in South Africa: An argument for a consensual approach. http://www.sarpn.org/documents/d0001015/. Accessed April 19, 2016.

OECD. (2015). African economic outlook 2015: Regional development and spatial inclusion. Paris: OECD. doi:10.1787/aeo-2015-en.

OPHI. (2013). Oxford poverty and human development initiative-Multidimensional poverty. http://www. ophi.org.uk/research/multidimensionalpoverty/. Accessed April 19, 2016.

Posel, D. (2004). Have migration patterns in post-apartheid South Africa changed? Journal of Interdisciplinary Economics, 15(3-4), 277-292.

Posel, D., Fairburn, J. A., \& Lund, F. (2006). Labour migration and households: A reconsideration of the effects of the social pension on labour supply in South Africa. Economic Modelling, 23(5), 836-853.

Qi, D., \& Wu, Y. (2014). Child poverty in China-A multidimensional deprivation approach. Child Indicators Research, 7(1), 89-118.

Ravallion, M. (2011). On multidimensional indices of poverty. Journal of Economic Inequality, 9(2), 235-248.

Rutstein, S. O. (2008). The DHS wealth index: Approaches for rural and urban areas. Calverton, MD: Macro International.

Rutstein, S. O., \& Johnson, K. (2004). The DHS wealth index. DHS comparative reports no. 6. Calverton, MD: ORC Macro.

Sahn, D. E., \& Stifel, D. C. (2000). Poverty comparisons over time and across countries in Africa. World Development, 28(12), 2123-2155.

Sahn, D. E., \& Stifel, D. C. (2003). Exploring alternative measures of welfare in the absence of expenditure data. Review of Income and Wealth, 49(4), 463-489.

Saisana, M., Saltelli, A., \& Tarantola, S. (2005). Uncertainty and sensitivity analysis techniques as tools for the quality assessment of composite indicators. Journal of the Royal Statistical Society, 168(2), 307-323.

Schreiber, J. B., Nora, A., Stage, F. K., Barlow, E. A., \& King, J. (2006). Reporting structural equation modeling and confirmatory factor analysis results: A review. Journal of Educational Research, 99(6), $323-338$.

Sen, A. (1993). Capability and well-being. In J. T. Roberts, A. H. Bellone, \& N. Chore (Eds.), The globalization and development reader: Perspectives on development and global change (pp. 525-549). Oxford and New York: Oxford University Press (second edition, 2015).

Shaffer, P. (2013). Ten years of "Q-squared": Implications for understanding and explaining poverty. World Development, 45, 269-285.

Silverman, B. W. (1981). Using kernel density estimates to investigate multimodality. Journal of the Royal Statistical Society: Series B, 43, 97-99.

Smits, J., \& Steendijk, R. (2014). The international wealth index (IWI). Social Indicators Research, 122(1), 65-85. doi:10.1007/s11205-014-0683-x.

Statistics South Africa Census. (2001). Household questionnaire. Pretoria: Statistics SA.

Steenkamp, J.-B. E., \& Baumgartner, H. (1998). Assessing measurement invariance in cross-national consumer research. Journal of Consumer Research, 25(1), 78-107.

Stifel, D., \& Christiaensen, L. (2007). Tracking poverty over time in the absence of comparable consumption data. The World Bank Economic Review, 21(2), 317-341.

Turok, I. (2012). Urbanisation and development in South Africa: Economic imperatives, spatial distortions and strategic responses. Urbanization and emerging population issues. Working Paper No. 8. Retrieved from http://www.delog.org/cms/upload/pdf-africa/Urbanisation_and_Development_in_ South_Africa_Economic_Imperatives_Spatial_Distortions_and_Strategic_Responses.pdf. Accessed November 9, 2015.

UNDP. (2010). Human development report 2010. The real wealth of nations: Pathways to human development. http://hdr.undp.org/sites/default/files/reports/270/hdr_2010_enreprint.pdf. Accessed November $21,2015$.

UNDP. (2015). Human development report 2015: Work for human development. New York: United Nations Development Programme. http://hdr.undp.org/sites/default/files/2015_human_development_report_1. pdf. Accessed September 21, 2016.

Vollmer, S., Holzmann, H., Ketterer, F., \& Klasen, S. (2013a). Distribution dynamics of regional GDP per employee in unified Germany. Empirical Economics, 44(2), 491-509. 
Vollmer, S., Holzmann, H., Ketterer, F., Klasen, S., \& Canning, D. (2013b). The emergence of three human development clubs. PLoS One, 8(3), e57624.

Vollmer, S., Holzmann, H., \& Schwaiger, F. (2013c). Peaks vs components. Review of Development Economics, 17(2), 352-364.

Vyas, S., \& Kumaranayake, L. (2006). Constructing socio-economic status indices: How to use principal components analysis. Health Policy Planning, 21(6), 459-468.

World Bank. (2015). The World Bank annual report 2015. Washington, DC: World Bank. https:// openknowledge.worldbank.org/handle/10986/22550. Accessed September 21, 2016.

Wright, G. (2008) Findings from the Indicators of Poverty and Social Exclusion Project: A Profile of Poverty using the Socially Perceived Necessities Approach, Key Report 7, Pretoria: Department of Social Development, Republic of South Africa.

Wright, G., \& Noble, M. (2007). South African index of multiple deprivation. Center for the Analysis of South African Social Policy. http://www.casasp.ox.ac.uk/imd.html\#SAIMD07_mun. Accessed October 5, 2015.

Zimmerman, F. J., \& Carter, M. R. (2003). Asset smoothing, consumption smoothing and the reproduction of inequality under risk and subsistence constraints. Journal of Development Economics, 71(2), 233-260. 